\title{
VALPROATE INDUCED NEPHROTOXICITY ON FETAL MICE KIDNEY
}

\section{Pratibha Shakya ${ }^{1}$, Neelesh Kumar Shakya ${ }^{* 2}$, C. Mohanty ${ }^{3}$.}

${ }^{1}$ Assistant Professor, Anatomy Department, Integral Institute of Medical Sciences \& Research, Integral University, Dasauli, Lucknow (U.P.), India.

${ }^{* 2}$ Forensic Medicine \& Toxicology, Assistant Professor, Department of Forensic Medicine \& Toxicology, Integral Institute of Medical Sciences \& Research, Integral University, Dasauli, Lucknow (U.P.), India.

${ }^{3}$ Professor \& Head, Anatomy Department, Institute of Medical Sciences, Banaras Hindu University, Varanasi (U.P.), India.

\section{ABSTRACT}

Background: Valproate is an antiepileptic drug which is also known as 2-propylvaleric acid. Valproic acid is presently the most widely used antiepileptic drug because of its antiepileptic effectiveness in a broad range of seizure types: tonic-clonic, myoclonic, absence and partial seizures. Present work was done to evaluate the gross and histological effect of valproate on fetal mice kidney.

Materials and Methods: This study was done in anatomy department of Institute of medical sciences, Banaras Hindu University, Varanasi (U.P.). Single dose of valproate $(200 \mathrm{mg} / \mathrm{kg})$ was administered intraperitoneally on $8^{\text {th }}$ day of gestation and then fetuses were collected at the $18^{\text {th }}$ day of gestation.

Results: Kidney was reduced in size in valproate treated group fetuses as compared to kidney of control group fetuses. On histological examination, distorted developing nephrons and clumping of bowman capsule in developed nephrons were seen.

Conclusions: Various authors worked on valproate treated adult mice kidney. There are only few study conducted on kidney of mice fetus. In present study, valproate was found teratogenic at the dose of $200 \mathrm{mg} / \mathrm{kg}$ so it should be avoided in human pregnancy if possible.

KEY WORDS: Valproate, Fetal mice, Kidney, Teratogenic.

Corresponding Author: Dr. Neelesh Kumar Shakya, M.D. Forensic Medicine \& Toxicology, Assistant Professor, Department of Forensic Medicine \& Toxicology, Integral Institute of Medical Sciences \& Research, Integral University, Dasauli, Lucknow (U.P.), India.

E-Mail: neelesh.shakya12@gmail.com

Access this Article online

Quick Response code

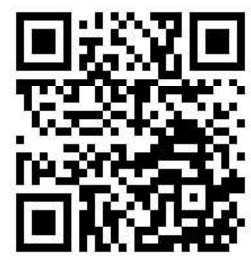

DOI: $10.16965 /$ ijar.2020.108

Journal Information

International Journal of Anatomy and Research

RG Journal ISSN (E) 2321-4287 | ISSN (P) 2321-8967

https://www.ijmhr.org/ijar.htm

DOI-Prefix: https://dx.doi.org/10.16965/ijar

Article Information

Received: 17 Jan 2020

Peer Review: 18 Jan 2020

Revised: None
Accepted: 12 Feb 2020

Published (O): 05 Mar 2020

Published (P): 05 Mar 2020

\section{INTRODUCTION}

Teratology means study of the causes, mechanisms and patterns of abnormal development. Teratology as a modern science was born in the 1930s with the publication of a set of experiments in which pregnant pigs were fed a dietdeficient in vitamin A. All of these piglets suffered a variety of malformations, predominantly lack of eyes [1]. The author concluded that nutritional deficiency leads to marked disturbance of the internal factors which control the mechanism of eye development. The physician Josef Warkany is considered the father of experimental teratology. In the 30 s and 40s of the past century, he was the first to prove that congenital developmental disorders can be 
induced by exogenous factors in mammals. His studies led to the definition of both genetic and environmentally induced structural defects [2].

Synthesis of Valproic acid was first done in 1882 by B.S. Burton. Valproic acid is also called as 2-propylvaleric acid. Valproic Acid is the most widely used antiepileptic drug (AED), Because it alleviates a broad range of seizure types: tonicclonic, myoclonic, absence and partial.Valproic acid has also shown to be therapeutically active in bipolar disorder, migraine and neuropathic pain. It is currently being trialled to focus on new indications like Alzheimer's disease, HIV and cancer therapy [3].

Valproic acid is an inhibitor of histone deacetylase. Recent studies have suggested that the teratogenicity of several compounds is linked to their ability to inhibit histone deacetylase. So histone deacetylation inhibition is one of the cause of producing teratogenic effects.

The term 'Fetal valproate syndrome' was given by Di Liberty in 1984 after studying various case reports of teratogenic effect of valproate.

When Valproic acid is used during pregnancy, it may cause various congenital anomalies like limb abnormalities, neural tube defects, heart defects, cleft palate, developmental delay, craniofacial abnormalities, inguinal and umblical hernia, supernumerary nipple, postaxial polydactyly, bifid ribs and preaxial defect of feet. However, the reports on valproate teratogenicity at $200 \mathrm{mg} / \mathrm{kg}$ dose is very limited in literature so the present study was designed to assess the teratogenic effects of valproate in fetuses of mice.

Aim of this research article is to study the macro and microscopic effect of Valproate on developing kidney.

\section{MATERIALS AND METHODS}

The present study was conducted in the Department of Anatomy, Institute Of Medical Sciences, Banaras Hindu University, Varanasi (U.P.). In present study, adult female Swiss albino mice weighing 20- $25 \mathrm{~g}$ (average age of 80-100 days) were used in the study after approval of institutional ethical committee. The drug was administered in a dose of $200 \mathrm{mg} / \mathrm{kg}$ in pregnant mice on $8^{\text {th }}$ gestational day intraperitonially. Equal volume of normal saline was given to pregnant control mice group through same route. Pregnant mice of both the groups were sacrificed on 18th day of gestation by cervical dislocation and fetuses were collected. After fixation of fetuses in $10 \%$ formalin for 48 hours, kidney of the fetuses were dissected out, photographed for any gross abnormality and further processed for histological observations.

\section{OBSERVATIONS}

On gross observation, kidney was reduced in size in valproate treated group fetuses as compared to kidney of control group fetuses [Figure1].

Fig. 1: Reduction in size of the kidney in fetuses exposed to Sodium valproate.

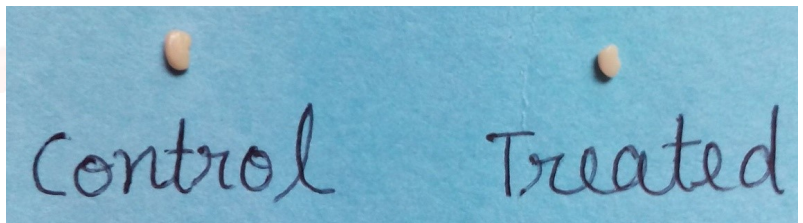

On histological examination of kidney, following microscopic features has been observed in single dose treated group [Figure3] as compared to control group [Figure 2].

Fig. 2: Control kidney showing (H \& E stain, 400x): Developing nephron in outer cortex (blue arrow). Fully developed nephron in inner cortex (black arrow).

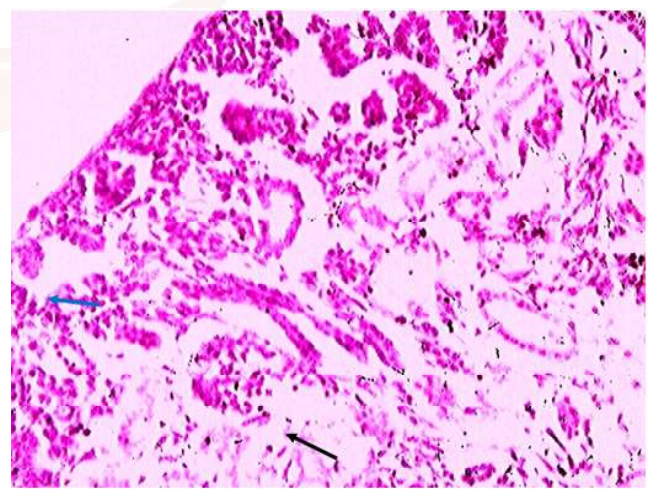

Fig. 3: Sodium valproate exposed kidney on GD-8 showing (H \& E stain, 400x): Distorted developing nephron in outer cortex (blue arrow). Clumping of bowman capsule in developed nephron in inner cortex (black arrow).

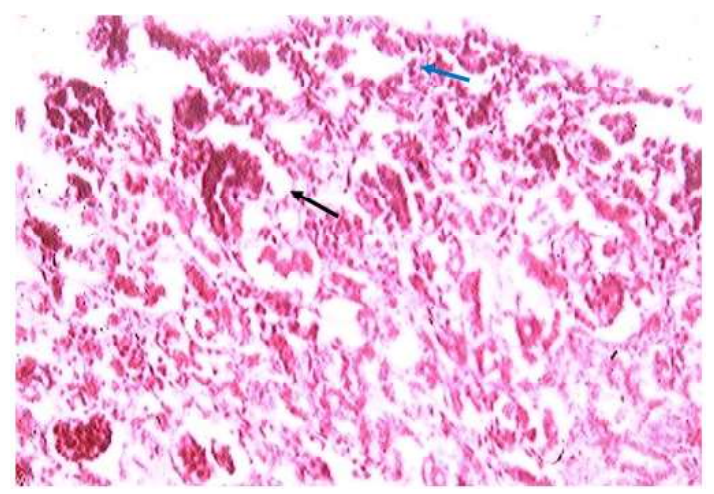




\section{DISCUSSION}

Present study reveals the nephrotoxicity of valproic acid. This nephrotoxicity may be due to teratogenic effects of valproic acid. Valproic acid crosses the placenta and is present in a higher concentration in the fetus than in the mother. This increased concentration of valproic acid in fetus may lead to renal toxicity. Further studies are needed to explain the exact underlying mechanism of histological changes in kidney.

There are only few study conducted on kidney of mice fetus.

Vorhees et al (1987) revealed 41\% visceral defects (hydronephrosis, cardiovascular defects, hypoplastic bladder ) in fetuses of Valproate ( $400 \mathrm{mg} / \mathrm{kg}$ dose on $7^{\text {th }}-18^{\text {th }}$ day of gestation) treated group [4]. Sonoda et al (1990) observed urogenital abnormality in fetuses of valproate treated mice [5].

Elmazar et al (1992) injected $500 \mathrm{mg} / \mathrm{kg}$ valproic acid on $8^{\text {th }}$ day of gestation and also found kidney abnormalities in mice fetus [6]. In a study by Kozma (2001), out of the total 69 cases, kidney defect was found in some cases [7]. Malm et al (2002) conducted a study in which two siblings were suffered from right kidney agenesis [8].

Aktas et al studied the effect of valproic acid on renal corpuscle of pregnal rats. Administration of single doses of valproate $\left(400 \mathrm{mg} / \mathrm{kg}\right.$ on $8^{\text {th }}$, $9^{\text {th }}$ and $10^{\text {th }}$ day of gestation) to pregnant rats resulted in degenerated changes of kidney at ultrastructural level [9].

\section{CONCLUSION}

Various authors worked on valproate treated adult mice kidney. There are only few study conducted on kidney of mice fetus. Present study concludes that valproate is teratogenic drug and has toxic effect on kidney so it should be used in human pregnancy very carefully.

\section{Conflicts of Interests: None}

\section{REFERENCES}

[1]. Hale F. Pigs born with eyebolls. J Hered 1933;24:105106.

[2]. Warkany J, Nelson RC. Appearance of skeletal abnormalities in the offspring of rats on a deficient diet. Science 1940;92:383-384.

[3]. Gottlicher M. Valproic acid: an old drug newly discovered as inhibitor of histone deacetylases. Annals of Hematology 2004;83:91-92.

[4]. Vorhees CV. Teratogenicity and developmental toxicity of valproic acid in rats. Teratology 1987;5:195202.

[5]. Sonoda T, Ohdo S, Ohba K, Okishima T, Hayakawa K. Teratogenic effects of sodium valproate in the $\mathrm{Jcl}$ : ICR mouse fetus. Acta Paediatr Jpn 1990;32:502507.

[6]. Elmazar MMA, Thiel R, Nau H. Effect of supplementation with folinic acid, vitamin $B_{6}$, and vitamin $B_{12}$ on valproic acid-induced teratogenesis in mice. Fundamental and Applied Toxicology 1992;18:389-394.

[7]. Kozma C. Valproic acid embryopathy: report of two siblings with further expansion of the phenotypic abnormalities and a review of the literature. Am J Med Genet 2001;98:168-175.

[8]. Malm $\mathrm{H}$ and Kajantie E. Valproate embryopathy in three sets of siblings: further proof of hereditary susceptibility. Neurology 2002;59:630-633.

[9]. Aktas A, Nergiz Y, Akkus M, Nasir Y. The effects of valproic acid on renal corpuscle of pregnant rats and protective role of folic acid andvitamin $E$. African journal of biotechnology 2010;9(34):56055610.

$$
\begin{aligned}
& \text { How to cite this article: } \\
& \text { Pratibha Shakya, Neelesh Kumar Shakya, C. Mohanty. VALPROATE } \\
& \text { INDUCED NEPHROTOXICITY ON FETAL MICE KIDNEY. Int J Anat } \\
& \text { Res 2020;8(1.3):7383-7385. DOI: 10.16965/ijar.2020.108 }
\end{aligned}
$$

